\title{
Diagnostic of gastrointestinal helminths in sands and canine feces from public locations in Alegre city, Espírito Santo - Brazil
}

\author{
Diagnóstico de helmintos gastrointestinais em areias e fezes \\ caninas de locais públicos no município de Alegre, Espírito \\ Santo - Brasil
}

\author{
Maria Larissa Bitencourt Vidal ${ }^{1}$ (D) Juliana Costa de Azevedo ${ }^{2}$ (D), Marcelle Temporim Novaes $^{3}$ (D) \\ \& Isabella Vilhena Freire Martins ${ }^{4 *}$ (1) \\ 'Veterinary, MSc. Universidade Federal do Espírito Santo - UFES, Alegre, ES, Brasil \\ ${ }^{2}$ Veterinary, autonomus. Francisco Beltrão, PR, Brasil \\ ${ }^{3}$ Pharmaceutical, autonomus. Vitória, ES, Brasil \\ ${ }^{4}$ Veterinary, Post doctor, Teacher. Universidade Federal do Espírito Santo - UFES, Alegre, ES, Brasil
}

\begin{abstract}
The aim of this experiment was to identify gastrointestinal helminths, also comparing different diagnosis parasitology technique in dog feces and sands samples from public locations in Alegre-ES. It was collected faecal samples from dogs and sands from public locations, such as parks, flower beds, sidewalks. These samples were sent to parasitology laboratory of the Veterinary Hospital of Centro de Ciências Agrárias e Engenharias of the Universidade Federal do Espírito Santo, where these samples were analyzed by Willis-Mollay and Simple Centrifugal-Flotation technique and the sands samples were analyzed by Baermann modified and Silva and others technique. A total of 92 faecal samples were analyzed, of which 60.7\% were positive for Ancylostoma spp., 24\% for Toxocara canis, 8.7\% for Dipylidium caninum and $1 \%$ for Taenia sp. In soil and sand samples hookworms larvae were found in 33.3\%. Simple Centrifugal-Flotation technique were more appropriated for parasites detection in dog feces, and Baermann technique was more appropriated to identify larvae in sands.
\end{abstract}

Keywords: coproparasitological techniques, dogs, helminths, soil contamination, zoonoses.

\section{Resumo}

Este trabalho teve como objetivo diagnosticar a frequência de helmintos gastrintestinais comparando diferentes técnicas usadas no diagnóstico de estruturas parasitárias presentes nas fezes de cães eno solo de locais públicos, no município de Alegre-ES. Foram coletadas amostras de fezes e areias em locais públicos como praças, canteiros, calçadas e essas foram encaminhadas para o laboratório de Parasitologia do Hospital Veterinário do Centro de Ciências Agrárias e Engenharias da Universidade Federal do Espírito Santo, onde as amostras de fezes foram analisadas pela técnica de Willis-Mollay e Centrífugo-Flutuação Simples e as de areia analisadas pela técnica de Baermann modificada e pela técnica de Silva e colaboradores. Foram analisadas 92 amostras de fezes e foram positivas 60,7\% para Ancylostoma spp., 24\% Toxocara canis, 8,7\% Dipylidium caninum. e 1\% Taenia sp. Nas amostras de solo e areia as larvas de ancilostomatídeos foram encontradas em 33,3\%. Foi observado ainda que a técnica de Centrífugo-Flutuação Simples foi mais apropriada para a detecção das formas parasitárias nas fezes de cães e que a técnica de Baermann foi mais apropriada no diagnóstico das larvas encontradas na areia.

Palavras-chave: técnicas coproparasitológicas, cães, helmintos, contaminação solo, zoonoses.

\section{Introduction}

Agglomeration of canine population in urban áreas associated with an increasing number of non-domiciled dogs has an important epidemiological role in soil contamination in public parks and squares and in infections spread by various parasite genus (Cassenote et al., 2011; Silva Mello et al., 2011).

The eggs, oocysts and larvae of the parasites are eliminated by animal feces, contaminating the environment, and most cycles are dependent on external environment conditions for their development. Several of these agents have zoonotic potential, with eggs and larvae potentially
How to cite: Vidal, M. L. B., Azevedo, J. C., Novaes, M. T., \& Martins, I. V. F. (2019). Diagnostic of gastrointestinal helminths in sands and canine feces from public locations in Alegre city, Espírito Santo - Brazil. Brazilian Journal of Veterinary Medicine, 41, e104619. doi: 10.29374/2527-2179. bjvm104619

Financial support: Higher Education Personne Improvement Coordination - Brazil (CAPES 001), the Federal University of Espírito Santo and the Espírito Santo Research and Innovation Support Foundation (FAPES).

Conflict of interests: No conflict of interests declared concerning the publication of this article.

Received: March 28, 2019.

Accepted: September 12, 2019.

The study was carried out at Laboratório de Parasitologia, Departamento de Medicina Veterinária, Universidade Federal do Espírito Santo - UFES, Alegre, ES, Brasil

\section{*Correspondence}

Isabella Vilhena Freire Martins

Departamento de Medicina Veterinária, Centro de Ciências Agrárias e Engenharias -

CCAE, Universidade Federal Rural do Espírito Santo - UFES

Alto Universitário, s/n - Guararema, Alegre CEP 29500-000 - Alegre (ES), Brasil

E-mail: isabella.martins@ufes.br
Copyright Vidal et al. This is an Open Access article distributed under the terms of the Creative Commons Attribution Non-Commercial License which permits unrestricted non-commercial use, distribution, and reproduction in any medium provided the original work is properly cited. 
reaching humans, such as Toxocara canis and T. cati, causing visceral larva migrans (VLM) and Ancylostoma braziliense and A. caninum, leading to cutaneous larva migrans (CLM) (Scaini et al., 2003; Rocha et al., 2011; Guimarães et al., 2005).

Child population is the most exposed due to greater contact with the soil, curiosity and discovery behavior, nutritional deficiencies or even apetite disturbances that make contact the soil with the mouth (Capuano \& Rocha, 2006). Therefore, checking the presence of eggs, oocysts and larvae in contaminated soil plays an importante role and occurs through techniques that detect them in soil particles, facilitating decision making for control measures (Oliveira et al., 2009).

The objective of this work was to evaluate the frequency of gastrointestinal helminths collected in public places, comparing diferent techniques used for parasitic structures diagnosis in dog feces and soil in public places of Alegre-ES.

\section{Material and methods}

Primarily it was selected locations in the city for faecal and sand samples collection, with dog feces occurring in open areas prioritizing the locations where there were stray animals in contact with the population.

Stool and sand samples were collected once a month, in the afternoon, choosing preferably fresh feces and also the nearby sand where the feces were found. Collection was done with a deep iron shovel of two centimeters and packed in plastic bags, later stored refrigerated and sent to Parasitology laboratory of the Veterinary Hospital of the Centro de Ciências Agrárias e Engenharias of the Universidade Federal do Espírito Santo.

Dog faecal samples sent to the laboratory were submitted to Willis-Molay (Willis, 1921) and Simple Centrifugal-Flotation techniques (Sloss et al., 1999). Sand samples were analysed by the techniques of Silva et al. (1991) and Baermann (Ueno \& Gonçalves, 1998). Once these samples arrived at the laboratory they were transferred to small plastic boxes without lid to promote oxygenation and placed in a BOD greenhouse at $26^{\circ} \mathrm{C}$ to perform analysis by Silva et al. (1991), undergoing 24 hours incubation for both technique applied.

The resulting eggs were identified based on the morphology described by Foreyt (2005) and Bowman (2010), and Dipylidium caninum diagnosis was target to proglottids observation in feces or by visualization of the ovigerous capsule in confirmed tests.

For statistical analysis, descriptive statistics were used to calculate parasites frequency and chisquare test $\left(\mathrm{X}^{2}\right)$ in the Epi info program (2006), using Yates correction and Fisher exact to evaluate diagnostic techniques.

\section{Results and discussion}

In a total of 92 dog feces samples, 56 (60.7\%), 23 (24\%), 8 (8.7\%) and 1 (1\%), respectively, were positive for Ancylostoma spp., Toxocara canis, Dipylidium caninum and Taenia spp., and also, from the total faecal samples analysed 25\% presented mixes infection for more than one helminth type. Table 1 shows the values found individually at each analyzed location.

Table 1. Number of samples collected and percentage of larvae found in soils and sands in the analyzed municipality of Alegre-ES.

\begin{tabular}{cccc}
\hline \multirow{2}{*}{ Locations } & Number of samples & \multicolumn{2}{c}{ Ancylostoma spp. } \\
\cline { 3 - 4 } & & Baermann & Silva \\
\hline Square & 18 & 16.7 & 27.8 \\
Sidewalk & 21 & 4.7 & 4.7 \\
Park & 2 & 100 & - \\
Flowerbed & 23 & 43.5 & 26 \\
School & 12 & - & - \\
kindergarten & 1 & - & - \\
\hline
\end{tabular}


Diagnosis of the structures obtained different results, e.g. 35 samples were positive for hookworm and 10 for toxocarids by Willis-Mollay technique, while by Simple Centrifugal-Flotation (SCF) it was obtained 49 and 21 positive samples, respectively. However, when analyzing the results for D. caninum and Taenia spp. by willis-mollay technique, positive samples were higher, once this technique diagnosed 8 samples for $D$. caninum, and one for Taenia sp.

SCF technique showed greater recovery of Ancylostoma spp. and Toxocara spp. when compared to Willis-Mollay ( $\mathrm{X}^{2}=45.02 \mathrm{p}<0.001$ for Ancylostoma sp. and $\mathrm{X}^{2}=24.62$ and $\mathrm{p}<0.001$ for Toxocara), hookworms were the most prevalente in both samples and techniques, followed by T. canis. Táparo et al. (2006) had already compared other techniques, reporting that Willis-Mollay technique for ancylostomatides and toxocarides diagnosis were more appropriate when compared to Faust, direct examination and sedimentation techniques.

Sprenger et al. (2014) collected feces and also soil contamination material to perform diagnosis by Faust, Lutz and Baermann methodoly, describing a total of 36\% positive samples for helminths and $65.2 \%$ areas classified as contaminated in one or more samples. The most identified helminth eggs were Ancylostoma sp. 14.5\%, followed by Toxocara sp. 9.6\% and Strongylida order, 2.3\% similar to the present study in the main helminths found.

Regarding statistical analysis of larval recovery techniques, the proportion of positive tests for Baermann was $25.64 \%$, while for Silva et al. (2011) the proportion was $14.10 \%$, demonstrating advantage of Baermann technique. $\left(X^{2}=7.52\right.$, with $\left.\mathrm{p}<0.01\right)$. From the 78 sand and soil samples collected, 26 were positive for Ancylostoma spp. larvae, identified by the presence of free-living nematode larvae.

Souza et al. (2008) studies with helminth eggs and larvae in day care centers sandboxes from municipal schools and public squares in Cuiabá - MT using Baermann technique (Ueno \& Gonçalves, 1998) for larval recovery and Hoffman et al. (1934) technique for helminth egg recovery, it was observed seven positive samples for helminth larvae. Baermann technique detected five larvae and Hoffmann two larvae, concluding that Baermann technique (Ueno \& Gonçalves, 1998) was more efficient for larval recovery, as shown in this presente work.

Mota et al. (2018) in their evaluation studies in samples from parks, schools and clubs in Uberlândia- MG, employing different techniques compared to this present study, reported eggs of Ancylostoma sp., $11.90 \%$ by Hoffmann technique and 4.76\% by Ritchie; Ascarididae eggs identification $5.43 \%$ and $12.5 \%$ respectively; and Strongyloides larvae $19.7 \%$ and $21.3 \%$, respectively.

Several authors found higher hookworms prevalence in distinct country regions, following by Toxocara genus (Oliveira et al., 2009; Silva et al., 1991; Sloss et al., 1999; Alves et al., 2005; Sousa et al., 2010; Táparo et al., 2006) as in other countries such as Portugal (Lebre, 2011), Nepal (Satyal et al., 2013) and Malaysia (Mahdy et al., 2012). Infection in non domiciled dog or in constant contact with public places was also cited with highest prevalence by other authors (Oliveira et al., 2009; Alves et al., 2005; Satyal et al., 2013).

Lower occurrence of $D$. caninum is also cited by more authors (Oliveira et al., 2009; Lebre, 2011; Mahdy et al., 2012) and its diagnosis is underestimated. This can be explained by difficult detection of ovigerous capsules in the stool (Gennari et al.,1999) or by inadequate exam method applied (Alves et al., 2005). It is noteworthy that in the present study the samples were considered positive by proglottids observation in feces or in the taken exams.

Regarding the execution of the techniques, no execution difficulties were found for stool samples, considering that Willis-Mollay and SCF use the principles of floatation based on saturated sugar solution, the difference is in the concentration and suspension of the sediment than in SCF, there is centrifugation and consequently at runtime, where SCF requires more time to perform. The techniques are simple and envolve the use of low cost materials and widely available, so they can be used in the laboratory routine (Matesco et al., 2011).

The high prevalence of parasites in dogs in municipality underscores hygienic-sanitary control problems, especially because they are zoonotic forms. High occurrences of hookworms and ascarids found in faecal waste from public places are due to the fact that non domiciled animals are more exposed to contaminated environment. Táparo et al. (2006) and Dryden et al. (2005) described that for the most accurate canine helminths diagnosis it is recommended to combine different coproparasitological techniques, such as sedimentation and flotation, to diagnose light and heavy eggs, different larval forms, and even to decrease the numbers of false negative results. 
The results of this work carried out in schools, kindergartens and other public environments were satisfactory, since in kindergartens no positive results were found. The school that was identified with contamination, was carried out socio-educational actions, aiming to indicate prophylaxis and prevention to prevent soil contamination, in order to make students and staff aware of the importance of impementhing hygiene practice to prevent future infections.

Soil analysis is an important criterion to be evaluated as well, considering that these samples are directly related to animal circulation and the presence of feces in public places.

Futhermore, there is a constant need to analyze dog and sand/soil feces from municipalities public environments, considering the possible occurrence of zoonotic parasite agentes, and also validation of techniques in laboratory routines aiming to improve diagnosis.

\section{Conclusion}

In the presente study, the highest frequency of gastroinstestinal helminths was hookworm. The simple flotation centrifuge technique was more suiatable for egg diagnosis, while Baermann's technique was more suitable for larval diagnosis.

\section{Acknowledgements}

This work was carried out with the support of the Higher Education Personnel Improvement Coordination-Brazil (CAPES 001), Federal University of Espírito Santo and Espírito Santo Research and Innovation Support Foundation (FAPES).

\section{References}

Alves, O. F., Gomes, A. G., \& Silva, A. C. (2005). Ocorrência de enteroparasitos em cães do município de Goiânia, Goiás: comparação de técnicas de diagnóstico. Ciência Animal Brasileira, 6, 127-133.

Bowman, D. D. (2010). Georgis: parasitologia veterinária. Rio de Janeiro: Elsevier.

Capuano, C. M., \& Rocha, G. M. (2006). Ocorrência de parasitas com potencial zoonótico em fezes de cães coletadas em áreas públicas do município de Ribeirão Preto, SP, Brasil. Revista Brasileira de Epidemiologia, 1(9), 81-86. http://dx.doi.org/10.1590/S1415-790X2006000100010.

Cassenote, A. J., Pinto Neto, J. M., Lima-Catelani, A. R., \& Ferreira, A. W. (2011). Contaminação do solo por ovos de geo-helmintos com potencial zoonótico na municipalidade de Fernandópolis, Estado de São Paulo, entre 2007 e 2008. Revista da Sociedade Brasileira de Medicina Tropical, 44(3), 371-374. http://dx.doi.org/10.1590/ S0037-86822011005000026. PMid:21552740.

Dryden, M. W., Payne, P. A., Ridley, R., \& Smith, V. (2005). Comparison of common fecal flotation techniques for the recovery of parasite eggs and oocysts. Veterinary Therapeutics, 6(1), 15-28. PMid:15906267.

Foreyt, W. J. (2005). Parasitologia veterinária: manual de referência (5a ed.). São Paulo: Roca.

Gennari, S. M., Kasai, N., Pena, H. F. J., \& Cortez, A. (1999). Ocorrência de protozoários e helmintos em amostras de fezes de cães e gatos da cidade de São Paulo. Brazilian Journal of Veterinary Research and Animal Science, 36(2), 87-91. http://dx.doi.org/10.1590/S1413-95961999000200006.

Guimarães, A. M., Alves, E. G., Rezende, G. F., \& Rodrigues, M. C. (2005). Ovos de Toxocara sp. e larvas de Ancylostoma sp. em praça pública de Lavras, MG. Revista de Saúde Pública, 39(2), 293-295. http://dx.doi. org/10.1590/S0034-89102005000200022. PMid:15895151.

Hoffman, W. A., Pons, J. A., \& Janer, J. L. (1934). The sedimentation concentration method in Schistosomiaisis mansoni. Journal of Public Health, 9, 281-289.

Lebre, F. L. M. C. R. (2011). Rastreio de parasitas gastrintestinais e seu impacto zoonótico em cães de canil da cidade de Lisboa (Dissertação de mestrado). Universidade Técnica de Lisboa, Lisboa. Retrieved in 2014, February 3, from https://www.repository.utl.pt/bitstream/10400.5/3073/1/Rastreio\%20de\%20Parasitas\%20 Gastrintestinais\%2Oe\%2Oseu\%2OImpacto\%2OZoonotico\%2Oem\%20Caes\%2Ode\%20Canil\%20da\%20 Cidade\%20de\%2OLisboa.pdf/

Mahdy, M. A. K., Lim, Y. A. L., Ngui, R., Fatimah, M. R. S., Choy, S. H., Yap, N. J., Al-Mekhlafi, H. M., Ibrahim, J., \& Surin, J. (2012). Prevalence and zoonotic potential of canine hookworms in Malaysia. Parasites \& Vectors, 5(88), 88. http://dx.doi.org/10.1186/1756-3305-5-88. PMid:22564445.

Matesco, V. C., Rott, M. B., \& Mentz, M. B. (2011). Comparação entre métodos de centrífugo-flutuação utilizados para a recuperação de ovos de helmintos em amostras de areia. Revista de Patologia Tropical, 40(4), 323-330.

Mota, K. C. P., Grama, D. F., Fava, N. M. N., Úngari, L. P., Faria, E. S. M., \& Cury, M. C. (2018). Distribution and risk factory of Ascarididae and other geohelminths in the soil of Uberlandia, Minas Gerais, Brazil. Revista do Instituto de Medicina Tropical de São Paulo, 60(0), 1-7. http://dx.doi.org/10.1590/s1678-9946201860017. PMid:29694601. 
Oliveira, V. S. F., Melo, D. P. G., Fernandes, P. R., Schulze, C. M. B., Guimarães, M. S., \& Silva, A. C. (2009). Ocorrência de helmintos gastrintestinais em cães errantes na cidade de Goiânia-Goiás. Revista de Patologia Tropical, 38(4), 279-283.

Rocha, S., Pinto, R. M., Floriano, A. P., Teixeira, L. H., Bassili, B., Martinez, A., Costa, S. O., \& Caseiro, M. M. (2011). Environmental analyses of the parasitic profile found in the sandy soil from the Santos municipality beaches, SP, Brazil. Revista do Instituto de Medicina Tropical de São Paulo, 53(5), 277-281. http://dx.doi.org/10.1590/ S0036-46652011000500007. PMid:22012454.

Satyal, R. C., Manandhar, S., Dhakal, S., Mahato, B. R., Chaulagain, S., Ghimire, L., \& Pandeya, Y. R. (2013). Prevalence of gastrointestinal zoonotic helminths in dogs of Kathmandu, Nepal. International Journal of Infection and Microbiology, 2(3), 91-94. http://dx.doi.org/10.3126/ijim.v2i3.8211.

Scaini, C. J., Toledo, R. N., Lovatel, R., Dionello, M. A., Gatti, F. A., Susin, L., \& Signorini, V. R. M. (2003). Contaminação ambiental por ovos e larvas de helmintos em fezes de cães na área central do Balneário cassino, Rio Grande do Sul. Revista da Sociedade Brasileira de Medicina Tropical, 36(5), 617-619. http://dx.doi.org/10.1590/S003786822003000500013. PMid:14576878.

Silva Mello, C., Mucci, J. L. N., \& Cutolo, S. A. (2011). Contaminação parasitária de solo em praças públicas da zona leste de São Paulo, SP-Brasil e a associação com variáveis meterológicas. Revista de Patologia Tropical, $40(3), 253-262$.

Silva, J. P., Marzochi, M. C. A., \& Santos, E. C. L. (1991). Avaliação da contaminação experimental de areias de praia por enteroparasitas. Pesquisa de ovos de helmintos. Cadernos de Saúde Pública, 7(1), 90-99. http://dx.doi. org/10.1590/S0102-311X1991000100008.

Sloss, M. W., Zajac, A. M., \& Kemp, R. L. (1999). Parasitologia clínica veterinária. Rio de Janeiro: Guanabara Koogan.

Sousa, V. R., Almeida, A. F., Cândido, A. C., \& Barros, L. A. (2010). Ovos e larvas de helmintos em caixas de areia de creches, escolas municipais e praças públicas de Cuiabá, MT. Ciência Animal Brasileira, 11(2), 390-395. http://dx.doi.org/10.5216/cab.v11i2.3150.

Souza, T. G. S., Dias, A. T., Vilela, F. M. P., Simoes, A. S., Nogueira, L. O., \& Oliveira, P. P. (2008). Ocorrência de larvas de Ancylostoma sp na areia de áreas de lazer de praças públicas no município de Juiz de Fora, MG, Brasil. HU Revista, 34(2), 123-125.

Sprenger, L. K., Green, K. T., \& Molento, M. B. (2014). Contaminação por geohelmintos em áreas públicas e fatores de risco epidemiológicos em Curitiba, Brasil. Revista Brasileira de Parasitologia Veterinária, 23(1), 69-73. http:// dx.doi.org/10.1590/S1984-29612014009. PMid:24728363.

Táparo, C. V., Perri, S. H. V., Serrano, A. C. M., Ishizaki, M. N., Costa, T. P., Amarante, A. F. T., \& Bresciani, K. S. (2006). Comparação entre técnicas coproparasitologicas no diagnóstico de ovos de helmintos e oocistos de protozoários em cães. Revista Brasileira de Parasitologia Veterinária, 15(1), 1-5. PMid:16646994.

Ueno, H., \& Gonçalves, P. C. (1998). Manual para diagnóstico das helmintoses de ruminantes (4a ed.). Tokio: Japan International Cooperation Agency.

Willis, H. H. (1921). A simple levitation method for the detection of hookworm ova. The Medical Journal of Australia, 2(18), 375-376. http://dx.doi.org/10.5694/j.1326-5377.1921.tb60654.x. 